\title{
DETECTION, PURIFICATION, AND IDENTIFICATION OF SIDEROPHORES PRODUCED BY Pseudomonas fluorescens ISOLATES USING SDS-PAGE AND HPLC. El-Sheikh, M. A. ${ }^{*}$; S. A. El-Kazzaz ${ }^{* *}$; E. E. Hafez ${ }^{* *}$; S. A. Madkour and Soha M. El-Gayyar \\ *Plant Pathology Dept., Faculty of Agric, Damanhour, Damanhour Univ. ** Plant Pathology Dept., Faculty of Agric., El-Shatby, Alex. Univ. \\ *** Plant Molecular Pathology Dept. City of Scientific Res.
}

\begin{abstract}
Three isolates of Pseudomonas fluorescens were isolated from the soil rhizosphere of potato growing fields and identification was confirmed by comparison of the morphological traits and physiological characteristics according to Murray et al., 1984 and Klement et al.,(1990). P. fluorescens isolates were tested to prove their ability in production of siderophores. Chrome Azurol Sulfonate assay (CAS assay) test was used to detect the presence of siderophores. Formation of an orange halo around a well bored into the CAS plate, was taken as an indication for the presence of siderophores. Concerning the optimization of conditions for highest production of siderophores on different media, the results revealed that king's B medium, exhibited the highest production of sidrophores. Also, data showed that $\mathrm{pH} 7$ and $27^{\circ} \mathrm{C}$ were the best in this respect while at $\mathrm{pH} 6$ and 8 sidrophores production completely inhibited. One of the siderophores gene was detected by specific primer in $P$. fluorescens and one band at molecular weight $520 \mathrm{bp}$ was observed. SDS-PAGE analysis was used to detect the possible outer membrane receptor protein (OMRP), in both whole cell pellet and membrane pellet at no iron and high iron concentration. The results revealed the existence of one band at $84 \mathrm{KDa}$ in case of no iron concentration. Purification of siderophores in culture supernatant was done by a sephadex G - $25 \mathrm{gel}$ filtration column. Nine fractions were obtained and they tested for siderophores activity by CAS assay. There were two types of siderophores in $P$. fluorescens culture supernatant (pyoverdin and pyochelin) and they were detected by high performance liquid chromatography (HPLC).
\end{abstract}

\section{INTRODUCTION}

Iron is a vital element required by virtually all living organisms, including bacteria. At low iron concentrations, bacteria are known to produce iron chelators called siderophores for ensuring their iron availability (Kathleen, 2007). The term "siderophore" is Greek for "iron carrier" and is so named because these molecules produced by micro organisms have an extremely high affinity for ferric iron (Landford,1973), thus siderophores bind iron and transport them to the cell. $P$. fluorescens as an example has the ability to suppress $R$. solanacearum. One of the mechanisms involved in disease suppression of potato is the production of antibiotic and siderophores. There are over 500 described siderophores had low molecular weight (350-1500 Daltons) as organic molecules (Wandersman and Deleplaire, 2004). Because of the high concentration of iron inside the bacterial cell and extremely low concentrations outside the cell, siderophores complexes are actively 
transported across membrane via outer membrane receptor protein (OMRP) (Buchanan et al., 2003). In general, the first step of entry of ferric siderophores into Gram-negative bacteria is mediated by specific outer membrane receptors. This transport into the periplasm requires the proton motive force (pmf) of the cytoplasmic membrane and an energy transduction complex, which includes the cytoplasmic membrane proteins TonB, ExbB and, ExbD (Erin, 2005). Although most siderophores are either hydroxamates or catechols, the chrome azurol sulfonate assay (CAS assay) has become widely used and may be applied on agar surfaces or in solution (Abigail, 2007). It is based on the colour change that accompanies transfer of the ferric ion from its intense. Raaska et al., (1992) detected the siderophores produced by $P$. fluorescens and $P$. chlororaphis from the culture supernatants by the universal Chrome azurol sulfonate assay (CAS assay) at wave lengths 620-690 nm. The CAS assay was applied to detect Pseudomonas siderophores directly in situ, and the most common detection method for siderophores production is the universal assay of Schwyn and Neilands (1987). The ability of Pseudomonas to grow and to produce siderophores is dependent on both the iron content and the type of carbon sources in the medium. Under conditions of low iron concentration the Pseudomonas isolates studied produced yellow-green fluorescent iron binding peptide siderophores, (Qarah et al., 2005). In addition, Djibaoui and Bensoltana (2005) reported that the highest siderophores concentrations were obtained from Pseudomonas culture in succinate medium. Similarly, Huiming et al., (1991) cleared that addition of iron to the culture medium resulted in increased culture growth with markedly decreased yield of siderophore. Also there are about six genes which were found to be responsible for siderophores production. Generally, $P$. fluorescens produces two types of siderophores which are pyoverdin and pyochelin. (Isabelle et al., 2001). P. aeruginosa and $P$. fluorescens produce an extracellular compound with yellowish green fluorescence, called pyoverdin, which functions as a siderophore. The production of pyoverdin, formerly called fluorescein, is concomitant with the production of another siderophore, pyochelin. Pyoverdin is produced by $P$. aeruginosa in several forms, some of which were separated on gel filtration columns and on reverse-phase, high-pressure liquid chromatography columns. An active form of iron-free pyoverdin was purified to homogeneity, Dany and Jean-morie, (1988), Alain et al., (2003) and Laurent et al., (2007). In addition, Huiming et al., (1991) purified siderophores that produced by $P$. fluorescens strain $\mathrm{V} 1$ using gel filtration chromatography, the molecular weight of the siderophores they identified estimated to be 1,000 Daltons. The objectives of this study were detection of siderophores produced by $P$. fluorescens, optimization of conditions for siderophores production by $P$. fluorescens, detection of one of the siderophores genes, and of possible outer membrane receptor protein (OMRP), purification of siderophores, identification of siderophores types by High performance liquid chromatography. It was hopped that results obtained from the present study could help in revealing the best antagonistic bacterial product to suppress variety of plant diseases. 


\section{MATERIALS AND METHODS}

\section{Preparation of fluorescent pseudomonads cultures and identification:-}

Fluorescent pseudomonads were isolated by serial dilution in king's $\mathrm{B}$ medium (KB) (proteose peptone, $1 \mathrm{~g} ; \mathrm{K}_{2} \mathrm{HPO}_{4} \cdot 3 \mathrm{H}_{2} \mathrm{O}, 0.15 \mathrm{~g} ; \mathrm{MgO}_{4} .7 \mathrm{H}_{2} \mathrm{O}$, 0.15 g; Glycerol, $1.5 \mathrm{ml}$; Agar, 2g; D.W., $100 \mathrm{ml}$., pH 7.2-7.4) (King et al., 1954) from potato rhizosphere. Cells were selected on king's $B$ medium and incubated at $30^{\circ} \mathrm{C}$ for $24 \mathrm{hr}$. Then cultures were examined under ultraviolet (UV) lamp at $430 \mathrm{~nm}$ to detect the presence of fluorescent colonies. A fluorescent pseudomonads bacterium was identified to species according to morphological and physiological tests recommended by Murray et al., (1984) and Klement et al., (1990) Table (1).

\section{Detection of siderophores production by $P$. fluorescens Chrome Azurol S (CAS) Assay}

The CAS Assay (Schwyn and Neilands, 1987) is the universal chemical assay for siderophores detection and is based on a siderophore's high affinity for ferric ion. CAS plates are blue in colour because chrome Azurol $S$ dye is complexed with ferric ion. When siderophores is present, an orange free dye is released (Erin, 2005).

$\mathrm{Fe}^{3+}$-dye (blue) + siderophore $\rightarrow \mathrm{Fe}^{3+}$ - siderophore + dye (orange)

$P$. fluorescens isolate $(G)$ which was the most antagonistic against $R$. solanacearum isolates according to previous study was chosen for further studies. This isolate was grown in King's B medium without phosphate. The medium consisted of (magnesium sulphate $1.5 \mathrm{~g} / \mathrm{l}$, Merk, Trypton $10 \mathrm{~g} / \mathrm{l}$, Difco, proteose peptone $10 \mathrm{~g} / \mathrm{l}$, Difco, glycerol $10 \mathrm{~m} / \mathrm{l}, \mathrm{BDH}$ ) and free from iron. KB medium supplemented with $0.5 \mu \mathrm{M} \mathrm{Fe}_{2}\left(\mathrm{SO}_{4}\right)_{3}$ (low iron) was used as well as with $20 \mu \mathrm{M} \quad \mathrm{Fe}_{2}\left(\mathrm{SO}_{4}\right)_{3}$ (high iron). Cultures of the tested isolate supplemented with iron concentrations were grown for $48 \mathrm{hr}$ on a rotary shaker and the supernatant from each was collected by centrifugation at $1000 \mathrm{rpm}$ for $10 \mathrm{~min}$ using $\mathrm{a} \pm 2$ cork borer, well were bored into a CAS plate and $60 \mu \mathrm{l}$ a liquots of each culture supernatant was pipetted into a separate well. Sterile media was also added to a well as a control. The plate was then incubated at room temperature. Depending on the culture, colour formation may take 30 minutes to $5 \mathrm{hr}$. Formation of an orange halo around the well indicate that culture is producing a siderophore.

Optimization of conditions for siderophore production:

Effect of iron concentrations and various carbon sources on bacterial growth and siderophores production:

Cultures were grown for $48 \mathrm{hr}$ at $27^{\circ} \mathrm{C}$ with shaking (150 rpm) in dark. The bacterial inocula were prepared by suspending a loopful of an actively growing in saline. The inoculum level was calibrated to give a turbidity of 0.04 . Three hundred $\mu \mathrm{l}$ of these inocula were suspended in $30 \mathrm{ml}$ of media. To remove traces of iron, glassware was cleaned with $6 \mathrm{M} \mathrm{HCl}$ and with double distilled water. Three basal media were employed with $\mathrm{FeCl}_{3}$ added in increasing amounts $(0,10,70,140,200,260 \mu \mathrm{g} / \mathrm{ml})$. The media contain the following components according to (Djibaoui and Bensoltana, 2005) 
- Succinate medium:- $\mathrm{KH}_{2} \mathrm{PO}_{4} 6 \mathrm{~g} / \mathrm{l}, \mathrm{K}_{2} \mathrm{HPO}_{4} 3 \mathrm{~g} / \mathrm{l}\left(\mathrm{NH}_{4}\right)_{2} \mathrm{SO}_{4} 1 \mathrm{~g} / \mathrm{l}$, $\mathrm{MgSO}_{4} .7 \mathrm{H}_{2} \mathrm{O} 0.2 \mathrm{~g} / \mathrm{l}$ sodium succinate., King's B medium:- magnesium sulphate $1.5 \mathrm{~g} / \mathrm{l}$, tryptone $10 \mathrm{~g} / \mathrm{l}$ proteose peptone $10 \mathrm{~g} / \mathrm{l}$, glycerol $10 \mathrm{ml} / \mathrm{L}$., Asparagine medium: asparagine $5 \mathrm{~g} / \mathrm{l}, \mathrm{MgSO}_{4} 0.1 \mathrm{~g} / \mathrm{l}$, and $\mathrm{K}_{2} \mathrm{HPO}_{4} 0.5 \mathrm{~g} / \mathrm{l}$. Bacterial growth was determined using plate count technique.

Effect of temperature on bacterial growth and siderophores production:

While most of $P$. fluorescens isolates grow at $25^{\circ}-35^{\circ} \mathrm{C}$, this may not the optimal temperature for siderophores production. Five flasks were prepared with $50 \mathrm{ml} \mathrm{KB}$ medium and inoculated with $P$. fluorescens isolate (G). The flasks containing the inoculated medium by $P$. fluorescens tested isolate were incubated at different temperatures $\left(20,25,27,30\right.$, and $\left.35^{\circ} \mathrm{C}\right)$.

Effect of $\mathrm{pH}$ on bacterial growth and siderophores production:

Six flasks containing KB medium were inoculated with $P$. fluorescens isolate at various $\mathrm{pH}$ degrees $(6,6.5,6.8,7,7.3$, and 8$)$.

Detection of one of siderophores genes by specific primer.

PCR amplification was carried out in the bacterial genomic DNA of the two isolates of $P$. fluorescens (one siderophores producer and the other nonproducer for siderophores) to study the presence/absence of siderophores using specific primers; the forward $5{ }^{`}$ CGC AAA TGC AGC AAC CGC AT 3 and the reverse 5 ACC TGG ACG AAG GTG GCC AT 3 '. The PCR was performed as follows: initial cycle with $95^{\circ} \mathrm{C}$ for 5 minutes and 34 cycles of $95^{\circ} \mathrm{C}$ for 1 minute, $60^{\circ} \mathrm{C}$ for 1 minute and $72^{\circ} \mathrm{C}$ for $10 \mathrm{~min}$. The PCR product was visualized on agarose gel $1 \%$ and photographed using gel documentation system. (Youard, et al., 2007).

Detection of possible outer membrane receptor protein (OMRP):

Preparation of sample for SDS-PAGE analysis:

$P$. fluorescens isolate $(\mathrm{G})$ was grown in $\mathrm{KB}$ medium for $48 \mathrm{hr}$ at $27^{\circ} \mathrm{C}$ in two shake flasks $(150 \mathrm{rpm})$ one with no added iron and other with $20 \mu \mathrm{M}$ $\mathrm{FeCl}_{3}$. Added cells were harvested by centrifugation at 10,000 rpm for $10 \mathrm{~min}$ and supernatant was discarded. Some of the whole cell pellet was saved and stored in an eppendorf tube at $-8^{\circ} \mathrm{C}$. The remaining pellet was resuspended in lysis buffer (PMSF $1 \mathrm{mM}$, 2-BMES mM, Tris $\mathrm{HCl} 50 \mathrm{mM} \mathrm{pH} \mathrm{8.8)} \mathrm{and}$ sonicated in an ice bath using a large probe (9.0, 9.0 second bursts of one minute with one minute pauses). Sonicated samples were centrifuged at $10,000 \mathrm{rpm}$ for $10 \mathrm{~min}$ and the supernatant was poured into ultracentrifuge tube. These were centrifuged at $30,000 \mathrm{rpm}$ for $90 \mathrm{~min}$ and resulting membrane pellets were stored at $-20^{\circ} \mathrm{C}$ (Buchanan et al., 2003).

\section{SDS-PAGE analysis of samples:}

Electrophoresis stock solutions

The stock solutions used for protein electrophoresis were as follows: $\mathbf{A}$. $30 \%$ Acrylamide stock solution (kept in dark at $4^{\circ} \mathrm{C}$ ):

Acrylamide (29 g), Bis-acrylamide (1 g), Deionized distilled water (Up to $100 \mathrm{ml}$ ). Any insoluble materials were removed by filtration through Whatman filter paper No.1. B. Sodium dodecylsulfate (10\% w/v SDS): Ten grams of sodium dodecylsulfate were dissolved in $100 \mathrm{ml}$ deionized distilled water. C. Ammonium persulphate solution $(10 \% \mathrm{w} / \mathrm{v})$ : One gram of ammonium persulphate was dissolved in $10 \mathrm{ml}$ deionized distilled water and kept at $4^{\circ} \mathrm{C}$. The solution unstable and must be made just before use. D. Buffers: I) 
Separating gel buffer $\left(1.5 \mathrm{M}\right.$ Tris- $\mathrm{HCl}, \mathrm{pH} 8.8$, kept in dark at $\left.4^{\circ} \mathrm{C}\right)$ : Trisbase $(18.15 \mathrm{~g})$ was dissolved in $50 \mathrm{ml}$ deionized distilled water and adjusted to $\mathrm{pH} 8.8$ using concentrated $\mathrm{HCl}$. The final volume was made up to $100 \mathrm{ml}$. II) Staking gel buffer $\left(0.5 \mathrm{M}\right.$ Tris- $\mathrm{HCl}, \mathrm{pH} 6.8$, kept in dark at $\left.4^{\circ} \mathrm{C}\right)$ : Tris-base $(6.05 \mathrm{~g})$ was dissolved in $50 \mathrm{ml}$ deionzed distilled water and adjusted to $\mathrm{pH}$ 6.8 using concentrated $\mathrm{HCl}$. The final volume was made up to $100 \mathrm{ml}$.

III) Electrophoresis buffer ( $\mathrm{pH}$ 8.3-8.5): The tank buffer consists of $3 \mathrm{~g}$ Trisbase, $14.4 \mathrm{~g}$ glycine and $1 \mathrm{~g}$ sodium dodecylsulphate dissolved in $1000 \mathrm{ml}$ deionized distilled water.

Separating and staking gel preparation: Vertical slab $(16 \times 18 \mathrm{~cm}) \mathrm{gel}$ electrophoresis apparatus (Bio-Rad, USA) was used. All glass plates were washed with deionized distilled water, then surface sterilized with ethanol. Spacers of $1.5 \mathrm{~mm}$ were used. Gels were prepared according to the protocol of Laemmli (1970). a] 12\% Separating gel (30 ml solution): $30 \%$ Acrylamide stock solution (12 ml); $1.5 \mathrm{M}$ Tris- $\mathrm{HCl}, \mathrm{pH} 8.8(7.5 \mathrm{ml}) ; 10 \%(\mathrm{w} / \mathrm{v})$ SDS $(0.3 \mathrm{ml}) ; 10 \%$ Ammonium persulphate solution $(0.3 \mathrm{ml})$; Deionized distilled water $(9.9 \mathrm{ml})$; TEMED added last $(12 \mu \mathrm{l})$. Separation gel solution was instantly swirled, then poured simultaneously to a height of $1.5 \mathrm{~cm}$ below the bottom of the comb and left to polymerize for at least $30 \mathrm{~min}$. Separating gels were overlaid with $1 \mathrm{ml}$ of water which removed before the stacking gel solution was poured. b] $5 \%$ Stacking gel ( $10 \mathrm{ml}$ solution): $30 \%$ Acrylamide stock solution (1.7 ml); $0.5 \mathrm{M}$ Tris- $\mathrm{HCl}(\mathrm{pH} 8.8) 1.25 \mathrm{ml} ; 10 \%$ (w/v) SDS 0.1 $\mathrm{ml} ; 10 \%$ Ammonium persulphate solution $0.1 \mathrm{ml}$; Deionized distilled water $(6.8 \mathrm{ml})$ TEMED $(10 \mu \mathrm{l})$. Stacking gels solution was quickly poured over the separating gel, and combs were used. Gels were left to polymerize for $30 \mathrm{~min}$ before running.

\section{Protein sample preparation:}

Sodium dodecyle sulphate (SDS) was add to the sample at a rate of 4 $\mathrm{mg} \mathrm{SDS} / 1 \mathrm{mg}$ protein, mixed with $50 \mu \mathrm{l}$ 2-mercaptoethanol then boiled at $100^{\circ} \mathrm{C}$ in water bath for 3-5 min.

\section{Loading and running of the samples:}

Twenty microlitters of each protein sample were loaded in the wells of the staking gel. The samples were covered with electrode buffer. Few drops of bromophenol blue $(4 \mathrm{mg} / 100 \mathrm{ml}$ deionized water) were added to the electrode buffer (tracking dye). Protein marker with molecular weight ranged from 1.4.4 to 116.6 KDa was used as standard. Electrophoresis was carried out at constant voltage of $100 \mathrm{~V}$ for $3 \mathrm{~h}$ in electrophoresis running buffer $(\mathrm{pH}$ 8.3-8.5).

\section{Staining and distaining of the gel:}

The gel was stained in $50 \mathrm{ml}$ of staining solution $(0.125 \%$ coomassie blue R-250, 50\% methanol and 10\% acetic acid) and then the gel was destained in a distaining solution (20\% methanol, $10 \%$ acetic acid, and $70 \%$ $\mathrm{H}_{2} \mathrm{O}$ ). The gel was placed between two sheets of cellophane membrane and dried on gel drier for $2 \mathrm{hr}$. and photographed by digital camera.

\section{Purification of siderophores:}

Culture supernatant ( 1 liter) from strain U7 was lyophilized; the residue was solved in $5 \mathrm{ml}$ of deionized water and centrifuged to remove the 
undissolved material. A 2-ml sample of this material was applied to a Sephadex G-25 (Pharmacia) gel filtration column $(1.5$ by $70 \mathrm{~cm}$ ) equilibrated with water-methanol $(10: 1, \mathrm{vol} / \mathrm{vol})$ as a solvent. Fractions of $3 \mathrm{ml}$ were collected and assayed for siderophores by CAS assay. The positive fractions were pooled, lyophilized, and resuspended in $1.0 \mathrm{ml}$ of water. Approximately $5 \mathrm{mg}$ of partially purified siderophore was obtained from 1 liter of culture supernatant. Fractions were also assayed for siderophore activity with CAS solution. (Kathleen 2007).

Identification of siderophores types by High Performance Liquid Chromatography (HPLC).

Liquid cultures were grown for 3 days. Culture was shaken for $20 \mathrm{~min}$, and the bacteria were removed by centrifugation (22 min, 10,000 rpm) and filtration through a $0.2-\mu \mathrm{m}$-pore-size membrane filter. The HPLC analyses were carried out by using the filtered culture media, the pyoverdin production was estimated by measuring the absorbance at $403 \mathrm{~nm}$ in order to determine the injection volume for the strain. The aim was to detect, by using HPLC, the retentions time (RT) of peaks with comparable heights. The HPLC analyses were performed with Nucleosyl $\mathrm{C}_{18}$ columns and a Waters 2190 system. The difference in $\mathrm{RT}(\Delta \mathrm{RT})$ (wavelength, $403 \mathrm{~nm}$ ) the culture medium of the strain was injected for a maximum of three analyses before or after each investigated strain. When the heights of the peaks were found to differ too much, the analyses were carried out again after readjustment of the injected volumes. Pyoverdin detection was performed by using the spectra of the molecules between 200 and $500 \mathrm{~nm}$ obtained with a Waters PDA 996 photodiode array detector. Two HPLC programs were used, in which solution A was a $17 \mathrm{mM} \mathrm{NaOH}$-acetic acid buffer $(\mathrm{pH} \mathrm{5.3)}$ and solution $\mathrm{B}$ was acetonitrile. HPLC program 1 was as follows (flow rate, $1 \mathrm{ml} / \mathrm{min}$ ): $100 \%$ solution A, $1 \mathrm{~min}$; from $100 \%$ solution $A$ to $97 \%$ solution $A, 2 \mathrm{~min} ; 97 \%$ solution A, 9 min; and from $97 \%$ solution A to $30 \%$ solution A, 25 min. HPLC program 2 (flow rate, $0.9 \mathrm{ml} / \mathrm{min}$ ) was as follows: $100 \%$ solution $\mathrm{A}, 8 \mathrm{~min}$; from $100 \%$ solution A to $98 \%$ solution A, 2 min; $98 \%$ solution A, 10 min; from $98 \%$ solution $A$ to $95 \%$ solution A, 5 min.; from $95 \%$ solution $A$ to $30 \%$ solution A, $15 \mathrm{~min}$; and $30 \%$ solution A, $5 \mathrm{~min}$. A pyoverdin production by $P$. fluorescens $(G)$ was initially carried out in King's $B$ medium by using HPLC program 1 (Alain et al., 2003).

\section{RESULTS}

\section{Identification of Pseudomonas fluorescens isolates}

Three isolates were identified as Pseudomonas fluorescens on the basis of their morphological and physiological characteristics. Data presented in Table (1) revealed that all the isolates were gram negative, non sporulating and motile. Meantime, the isolates exhibited positive reaction for fluorescence on KBA medium, growth at $4^{\circ} \mathrm{C}, \mathrm{pH} 7$, levan formation and gelatin liquefaction. However, the isolates showed negative reaction for starch hydrolysis, growth at $41^{\circ} \mathrm{C}$ and in $7 \% \mathrm{Nacl}$. 


\section{Detection of siderophores production by $\boldsymbol{P}$. fluorescens}

CAS assay was used to determine the ability of $P$. fluorescens to produce siderophores. Formation of an orange halo around a well bored into the CAS plate indicates that siderophores is present in the supernatant of cultures. These results indicated that $P$. fluorescens produces siderophores under no iron and low iron respectively, while siderophores were not produced when sufficient iron was available in the medium for the bacterium tested Fig (1).

Table (1): Morphological and physiological characteristics of the antagonistic Pseudomonas fluorescens isolates.

\begin{tabular}{|l|c|c|c|}
\hline \multicolumn{1}{|c|}{ Characteristics } & G & H & I \\
\hline Gram Staining & - & - & - \\
Sporulation & - & - & - \\
Fluorescene on KBA & + & + & + \\
Motility & + & + & + \\
Growth at $41^{\circ} \mathrm{C}$ & - & - & - \\
Growth of $4{ }^{\circ} \mathrm{C}$ & + & + & + \\
Growth at $\mathrm{pH} 7$ & - & + & + \\
Growth in $7 \% \mathrm{NaCl}$ & + & - & - \\
Levan formation & + & + & + \\
Gelatin liquefaction & - & - & + \\
\hline Starch hydrolysis & & - \\
\hline
\end{tabular}

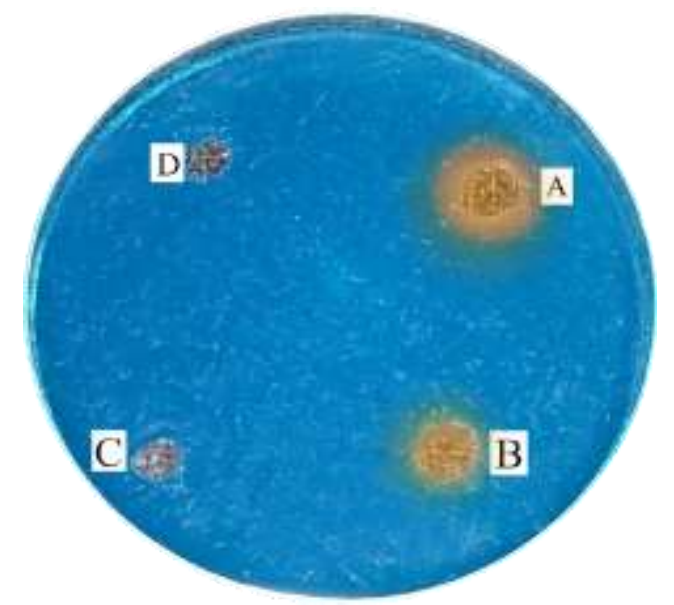

Fig. (1): CAS assay plate for $P$. fluorescens isolate tested $A$ ) no added iron. B) $0.5 \mu \mathrm{M} \mathrm{Fe}\left(\mathrm{So}_{4}\right)_{3}$ (low iron). C) $20.0 \mu \mathrm{M} \mathrm{Fe}\left(\mathrm{So}_{4}\right)_{3}$ (high iron). D) un-inoculated media (control).

Optimization of conditions for siderophores production:

Effect of iron concentrations and various carbon sources on bacterial growth and siderophores production:

Iron concentration is probably the single most important factor in how much an organism produces siderophores, as genes for siderophores biosynthesis are expressed under the direct control of iron concentration in 
the environment. Data presented in Table (2) showed that King's B was the most suitable for bacterial growth with average of 1.7 , followed by succinate (1.13) and Asparagine medium (0.96) respectively. The maximum bacterial growth was observed at $200 \mathrm{mg} / \mathrm{L}$ on King's B, followed by Succinate and Aspargine where exhibited values (2.07), (1.40) and (1.31) respectively. However, at $0.0 \mathrm{mg} / \mathrm{L}$ iron concentration, bacterial growth was noticed, but, markedly less than the other concentrations. Significant differences were observed between King's B medium and the two other media i.e Succinate and Asparagine, however, significant differences were not detected between Succinate and Asparagine medium on bacterial growth. Results revealed that the increase in iron concentration was correlated with decrease in siderophores production even completely suppressed at $260 \mathrm{mg} / \mathrm{L}$ concentration of iron on the three media tested. King's B medium exhibited the highest production of siderophores at $(0.0)$ iron concentration where induced value (35.04) followed by Succinate (31.04) and Asparagine (28.96). Significant differences were not observed between King's B (23.55) and Succinate medium (21.10), but Aspargine medium (15.16) significantly differed from the other media. Generally, King's B medium exhibited the highest production of sidrophores followed by Succinate and Asparagine respectively.

Table (2): Effect of iron concentrations and various carbon sources on bacterial growth and siderophores production.

\begin{tabular}{|c|c|c|c|c|c|c|c|c|}
\hline \multirow{2}{*}{$\begin{array}{l}\mathrm{Fe}^{3+} \\
\mathrm{Conc} \\
\mathrm{mg} / \mathrm{L}\end{array}$} & \multicolumn{4}{|c|}{ Bacterial growth* } & \multicolumn{4}{|c|}{ Siderophores production } \\
\hline & $\begin{array}{c}\text { King's } \\
\text { B }\end{array}$ & Succinate & Aspargine & Mean & $\begin{array}{c}\text { King's } \\
B\end{array}$ & Succinate & Aspargine & Mean \\
\hline 0 & 1.50 & 0.98 & 0.86 & 1.113 & 35.04 & 31.04 & 28.96 & $31.86^{\mathrm{a}}$ \\
\hline 10 & 1.88 & 0.95 & 0.82 & 1.216 & 31.51 & 29.51 & 28.0 & $29.67^{\text {ab }}$ \\
\hline 70 & 1.90 & 1.25 & 1.24 & 1.463 & 29.91 & 29.06 & 20.0 & $26.32^{\mathrm{ab}}$ \\
\hline 140 & 1.96 & 1.33 & 1.14 & 1.476 & 24.82 & 26.0 & 14.0 & $21.60^{b}$ \\
\hline 200 & 2.07 & 1.40 & 1.13 & 1.593 & 20.0 & 11.0 & 0.01 & $10.34^{c}$ \\
\hline 260 & 0.87 & 0.87 & 0.40 & 0.713 & 0.0 & 0.0 & 0.0 & $0.0^{\mathrm{d}}$ \\
\hline Mean & $1.70^{\mathrm{a}}$ & $1.13^{b}$ & $0.96^{b}$ & & $23.55^{a}$ & $21.10^{\mathrm{a}}$ & $15.16^{b}$ & \\
\hline $\begin{array}{c}\text { L.S.D } \\
\text { carbon for } \\
\text { sources }\end{array}$ & \multicolumn{4}{|c|}{0.211} & \multicolumn{4}{|c|}{4.99} \\
\hline $\begin{array}{c}\text { L.S.D } 0.05 \mathrm{~F}^{+3} \\
\text { conc. }\end{array}$ & \multicolumn{4}{|c|}{0.297} & \multicolumn{4}{|c|}{7.06} \\
\hline
\end{tabular}

Means followed by the same letter (s) are not significantly different according to L.S.D 0.05 values. ${ }^{*}$ each value $\times 10^{7}$ estimated as colony forming unit (cfu).

\section{Effect of temperature on bacterial growth of $P$. fluorescens and} siderophores production:

Data in Table (3) showed that both growth and siderophores production are highest at $27^{\circ} \mathrm{C}$, where that degree exhibited values 1.9 and 38.06 respectively. Such results cleared that $27^{\circ} \mathrm{C}$ was the most suitable for bacterial growth and siderophores production. Results also revealed that the higher temperature, the lowest growth as well as siderophores production even completely suppressed at $35^{\circ} \mathrm{C}$. 
Table (3): Effect of temperature on bacterial growth of $\boldsymbol{P}$. fluorescens and siderophores production.

\begin{tabular}{|c|c|c|}
\hline Temperature $^{\circ} \mathbf{C}$ & Bacterial growth* & Siderophores production \\
\hline 20 & 0.00 & 0.00 \\
\hline 25 & 1.15 & 29.45 \\
\hline 27 & 1.90 & 38.06 \\
\hline 30 & 1.01 & 0.01 \\
\hline 35 & 0.00 & 0.00 \\
\hline
\end{tabular}

Effect of $\mathrm{pH}$ on bacterial growth of $P$. fluorescens and siderophores production.

Data presented in Table (4) revealed that the highest production of siderophores by $P$. fluorescens was induced at $\mathrm{pH} \mathrm{7,} \mathrm{however,} \mathrm{this} \mathrm{value} \mathrm{of}$ $\mathrm{pH}$ did not exhibit the highest growth of bacterial isolate tested. Bacterial growth and siderophores production completely inhibited at $\mathrm{pH} 8$ as well as $\mathrm{pH} 6$.

Table (4): Effect of $\mathrm{pH}$ on bacterial growth of $\boldsymbol{P}$. fluorescens and siderophores production.

\begin{tabular}{|c|c|c|}
\hline $\mathbf{p H}$ & Bacterial growth $^{*}$ & Siderophores production \\
\hline 6 & 0.00 & 0.00 \\
6.5 & 0.65 & 0.00 \\
6.8 & 1.02 & 15.22 \\
7 & 1.70 & 39.28 \\
7.3 & 2.01 & 24.55 \\
8 & 0.00 & 0.00 \\
\hline
\end{tabular}

Detection of one of siderophores genes by specific primer

Specific primer was used to study the presence of one of siderophores gene in $P$. fluorescens isolate $(G)$ which known to produce siderophores and another bacterial isolate $(\mathrm{O})$ non producer for siderophores. Date illustrated in Fig (2) showed that one band at molecular weight $520 \mathrm{bp}$ was present in $P$. fluoresens isolate $(G)$ and absent in another isolate $(O)$.

SDS/PAGE analysis was performed on whole cell pellets and membrane pellets of cultures of the tested $P$. fluorescens isolate grown in a no-added iron medium as well as a high iron medium to detect a possible OMRP involved in siderophores transport. Results revealed that the protein was expressed in the no-added iron pellets, while it repressed in high iron concentrations. The molecular weights for most described OMRPs are in the range of $80-85$ kilodaltons $(\mathrm{kDa})$. The SDS/PAGE gel in Fig (3) shows the presence of a band in this molecular weight range that is only present in the no added iron cultures, indicating that it is regulated by the amount of iron in the medium. This protein is likely involved in siderophores transport 
El-Sheikh, M. A. et al.

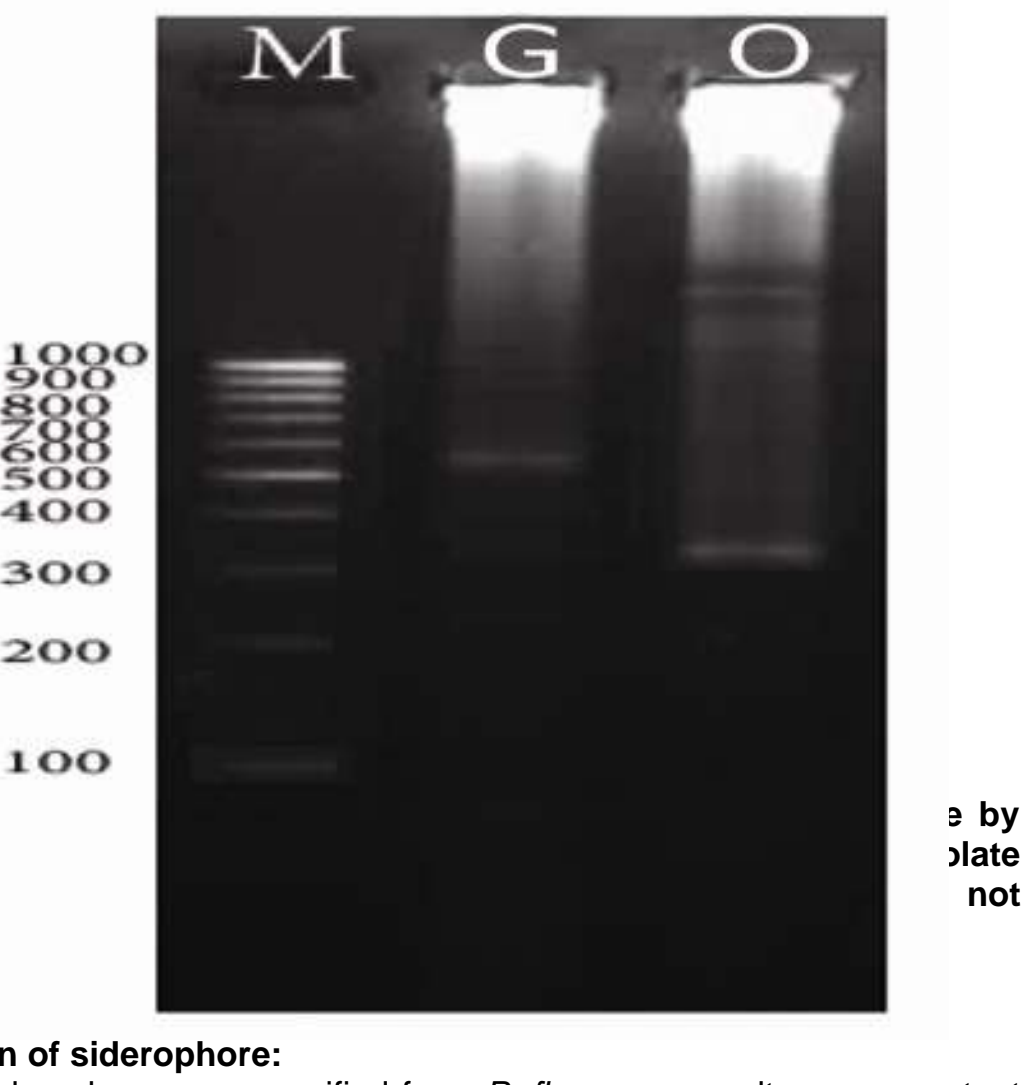

Detecti

Purification of siderophore:

The siderophores were purified from $P$. fluorescens culture supernatant by Sephadex G-25 gel filtration column. Data showed that 9 fractions were collected and assayed for CAS activity. Two fractions were positive to CAS assay and others were negative.

\section{Identification of siderophores types by High Performance Liquid Chromatography (HPLC): \\ The two positive fractions were analyzed by HPLC. The HPLC method of analyzing siderophores production presented in this study proved to be a very powerful method. Data presented in Fig (4) indicated that there were two types of siderophores pyochelin and pyoverdin.}




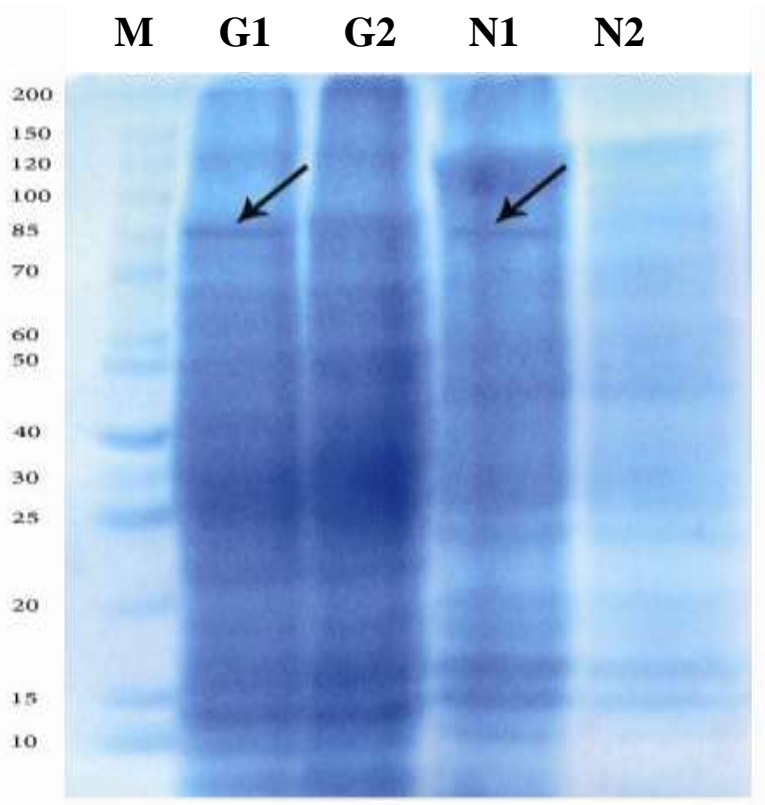

Fig. (3) SDS-PAGE analysis of whole and membrane pellets of $P$. fluorescens : $M)$ molecular weight standard $G_{1}$ : whole cell pellet in case of $P$. fluorescens grown in a (no added iron medium), $G_{2}: P$. fluorescens grown in a high iron medium.

$\mathbf{N}_{1}$ : Membrane pellet in case of $P$. fluorescens grown in a (no added iron medium), $\mathbf{N}_{2}: P$. fluorescens grown in a high iron medium.

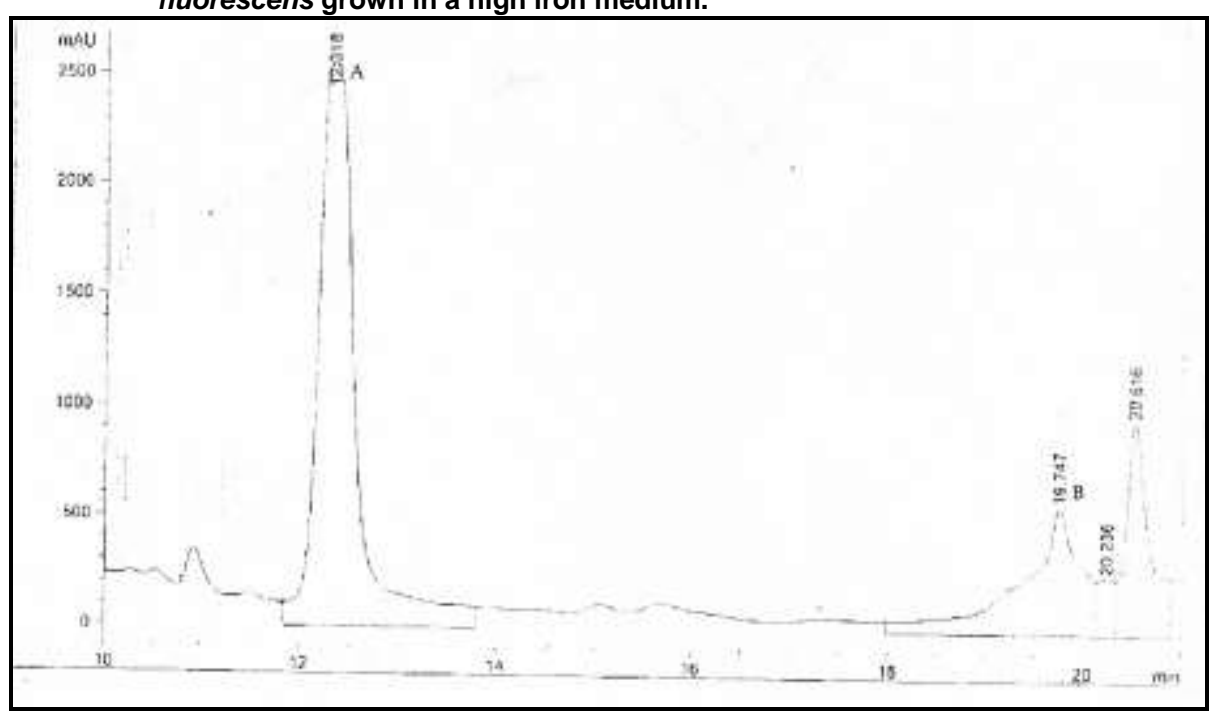

Fig.(4): High Performance Liquid Chromatography of siderophores A: pyoverdin and B: pyochelin) produced by $P$. fluorescens (G) isolate. 


\section{DISCUSSION}

On the basis of the results obtained, three isolates of $P$. fluorescens were isolated from rhizosphere of potato fields and identified according to morphological and biochemical characteristics recommended by Murray et al., (1984) and Klement et al., (1990). Results indicated that the three isolates of $P$. fluorescens were gram negative, non sporulating and exhibited negative reaction for starch hydrolysis, growth at $41^{\circ} \mathrm{C}$ and in $7 \%$ Nacl. However, the isolates induced positive reaction in case of fluorescence on KBA medium, growth at $4^{\circ} \mathrm{C}, \mathrm{pH} 7$, levan formation and gelatin liquefaction. $P$. fluorescens had the ability to synthesize a wide range of secondary metabolites. Among those were iron-chelating compounds called siderophores. Our results indicated that an orange halo around the well bored in the solid medium was noticed, and the CAS plate assay was blue in colour because chrome Azurol $S$ dye is complexed with ferric ion. When the siderophores are present, they react with iron and the dye released which is orange colour. This result agreed with Huiming et al., (1991), Erin, (2005), and Abigail, (2007). Concerning, conditions that optimized for siderophores production were temperature, $\mathrm{pH}$, iron concentration in the media and various carbon sources. Siderophores are iron-specific compounds which are secreted under low iron stress and the production of siderophores in the medium employed was inversely proportional to the iron concentration in the medium. Data in the present study indicated that the medium free from iron induced the higher production of siderophores. Besides, data presented indicated that the higher the iron concentrations, the lowest growth and sidrophore production. Our results indicated that siderophores production was the highest at $(0.0)$ iron concentration and decreased as the iron concentration increased even completely depressed at $260 \mathrm{mg} / \mathrm{L}$. These results are in agreement with Budzikiewicz, (1993), Qarah et al., (2005), Djibaoui and Bensoltana, (2005) and Katheleen (2007), where they reported that siderophores production positively induced under iron-stress. When $P$. fluorescens was grown in three different media, i.e. Succinate medium, Asparagine medium and king's B medium it could be concluded from our results that King's B medium induced the highest siderophores production. Significant differences were detected between King's B and the other two media i.e. Succinate and Asparagine. Such results were in contradictory with Djibaoui and Bensoltana (2005) where they reported that the highest siderophores production was obtained in Succinate medium while, were in harmony with them where they showed that iron increased the growth yield of bacteria and repressed siderophores production at levels above $200 \mu \mathrm{g} / \mathrm{l}$, but had a positive effect below $160 \mu \mathrm{g} / \mathrm{l}$. Data showed that the highest production of siderophores was induced at 27 ${ }^{\circ} \mathrm{C}$ and the higher the temperature, the lowest growth as well as siderophores production even completely inhibited at $35^{\circ} \mathrm{C}$. Also, our results revealed that the highest production of siderophores at $\mathrm{pH} 7$ (neutral), and depressed at $\mathrm{pH}$ 8 as well as pH 6. Concerning the detection of one of siderophores gene in $P$. fluorescens isolate which is known to produce siderophores and in another bacterial isolate that did not produce siderophores, our results showed that 
one band at $520 \mathrm{bp}$ was found in $P$. fluorescens isolate $(\mathrm{G})$ and absence in the another isolate $(O)$. These results somewhat agreed with those reported by Isabelle et al., (2001), Michelle et al., (2004), and Youard et al.,.(2007). We have also detected a possible outer membrane receptor gene protein (OMRP) involved in the transport of siderophores in $P$. fluorescens. This possible receptor is detected only under no iron concentration and falls into the molecular weight range $(84 \mathrm{kDa})$ and this band did not found in the whole cell pellet or membrane pellet in high iron concentration. This was in agreement with Dimitris et al. (1999), Van der Helm and Chakraborty, (2001), Ferguson et al., (2002), and Buchanan et al., (2003). The HPLC method of analyzing siderophores production presented proved to be a very powerful method for rapidly determining. Results in this study revealed that existence of two types of siderophores and this result were similar to those reported by Dany and Jean-morie (1988), Alain et al., (2003), and Laurent et al., (2007).

\section{REFERENCES}

Abigail, M. (2007). Identification and structural characterization of siderophores produced by halophilic and alkaliphilic. Ph.D. Thesis, Washington State University.

Alain, B., Isabelle, G., Bernard, W., Henri, M. and Edmond, H. (2003). HighPerformance Liquid Chromatography Analyses of Pyoverdin Siderophores Differentiate among Phytopathogenic fluorescent Pseudomonas Species. Appl environ microbial vol:69(2).1143-1153.

Buchanan, S.K., Smith, B.S., Venkatramani, L., Esser, L., Palnithkar, M., Chakraborty, R.,Van der Helm, D. and Deisenhoffer, J. (2003). Crystal structure of the outer membrane active transport FePA from Escherichia coli. Nat. Struct. Biol. Vol:6: 56-62.

Budzikiewicz, H. (1993). Secandry metabolites from fluorescent Pseudomonas. FFMS Microbial.Rev.104:209-228.

Dany, H. and Jean-morie, M. (1988). Specificity of pyoverdine-Mediated Iron uptake among fluorescent Pseudomonas strains. Journal of Bacteriology. Oct., pp: 4865-4873.

Dimitris, M., Jean-Marie, M., Herbert, B. and Ulrich, W. (1999). Guinolobuctin a new siderophore of Pseudomonas fluorescens 17400. The production of which is repressed by the congnate pyoverdine.

Djibaoui, R. and Bensoltana, A. (2005). Effect of iron and growth inhibitors on siderophores production by Pseudomonas fluorescens. African Journal of Biotechnology Vol.4 (7) pp.697-702.

Erin, P.S. (2005). Isolation, purification and chemical characterization of the Dihydroxamate-type siderophore. Schizokinen, "produced by Rhizobium leguminosarum. M.Sc. Thesis, Faculty of the Department of Health Sciences East Tennessee State University.

Ferguson, A. D., Chakaraborty, R., Smith, B. S., Esser, L., Van der Helm, D. and Deishofer, D. (2002). Structural basis of gating by the outer membrane transporters FeCA. Science. Vol: 295:1658-1659. 
Huiming, Y., Wipada, C. and Pamela, A.S. (1991). Siderophore production by Pseudomonas pseudomallei. Infection and Immuninity, Mar., p. 776780.

Isabelle, J., Schalk, I., Christophe, H. and Keith, P. (2001). Iron-free pyoverdin binds to its outer membrane receptor FpvA in Pseudomonas aeruginosa: a new mechanism for membrane iron transport. Molecular Microbiology, 39 : 351-360.

Kathleen, M.M. (2007). Biochemistry of siderophores biosynthesis. PhD. Thesis. University of Kansas.

King, E.O., Ward, M.K. and Randy, D.E. (1954). Two simple media for the demonstration of Pyocyanin and fluorescent. Journal of Laboratory and Clinical Medicine 44 : 301-307.

Klement, Z., Rudolph, K. and Sands, D.C. (1990). Methods in Phytopathology. Akademiai Kiado. Budapest, pp. 133-143.

Laemmli,U. K. (1970). Cleavage of structural proteins during the assembly of head of bacteriophage T4. Nature, 227:680-685.

Landford, C. E. (1973). Bacterial assimilation of iron. Crit. Rev. Microbiol. 2: 273-331.

Laurent, B., B. Aude., and R. Cornelia. (2007). Ferripyochelin uptake genes are involved in pyochelin-mediated signalling in Pseudomonas aeruginosa. Microbiology. 153: 1508-1518.

Michelle, R.R., Katie, S.B. and Michael, G., Thamas, B. (2004). Identification and analysis of a siderophore biosynthetic gene cluster from Agrobacterium tumefaciens. Microbiology, 150, 3857-3866.

Murray, M., Noel, R., Krieg, J., Holt, G., Williams and Wilkins (1984). Bergey's Manual of systematic Bacteriology. 9th Ed., 140-199, 1109-1134 Eds., London.

Qarah, S., Cunha, B.A., Dua, P. and Lessnau, K.D. (2005). Pseudomonas aeruginosa infection. www.emedicine.com.

Raaska, L., Viikari, L. and Mattila, T. (1992). Detection of siderophores in growing cultures of Pseudomonas spp. Journal of Industrial Microbiology, 11 (1993): 181-186.

Schwyn, B. and Neilands, J.B. (1987). Universal chemical assay for the determination of siderophores. Anal. Biochem. 160: 47-56

Van der Helm, D. and Chakaroborty, R. (2001). Structures of siderophores receptors, p 261-287. In G. Winkelmann (ed.). Microbial Transport Systems. Wiley-VCH, Weiheim, Germany.

Wandersman, C. and Delepelaire, P. (2004). Bacterial iron sources: from siderophores to hemophores. Annu. Rev. Microbiol. 58: 611-647.

Youard, Z.A., Gaëtan, L.A.M., Panl, A.M., Isabelle, J.S. and Cornelia, R. (2007). Pseudomonas fluorescens CHAo Enantio-Pyochelin, the optical antipode of the Pseudomonas aeruginosa siderophore pyochelin. The Journal of biological Chemistry Vol, 282, No, 49, pp. 546-553. 
اكتشاف وتنقية وتعريف السيدروفورز المفرزة بواسطة البكتيرة سيدوموناس

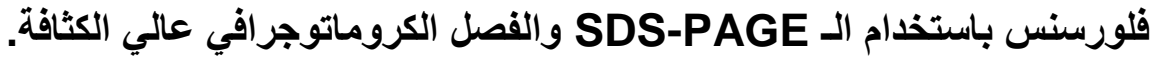

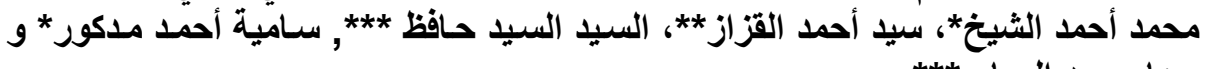

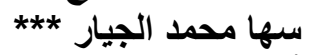

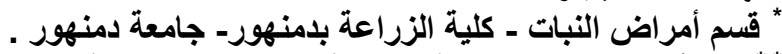

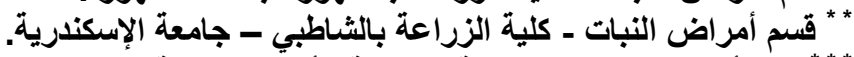

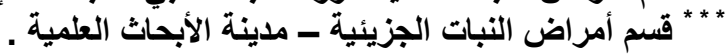

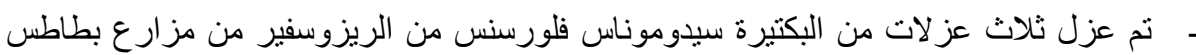

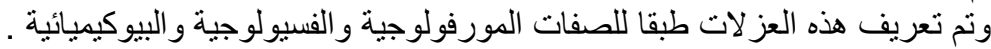

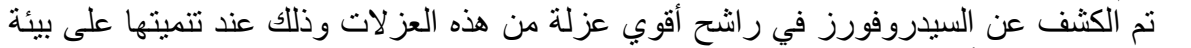

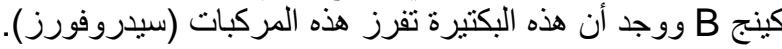

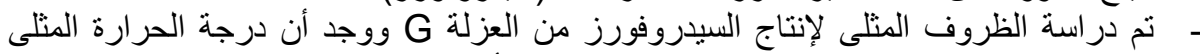

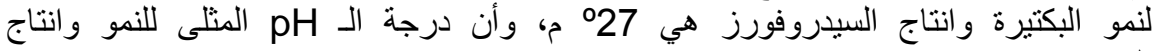
السيدروفورز هي 7.

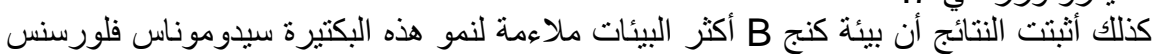

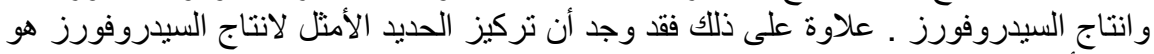

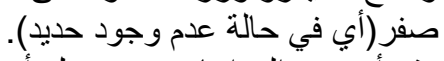

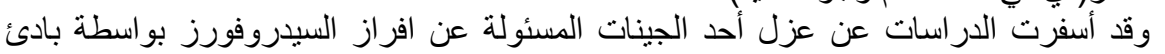

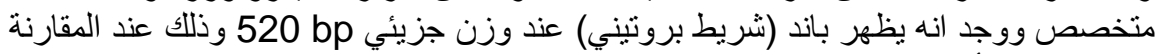

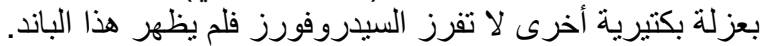

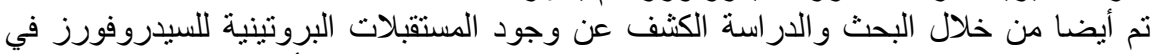

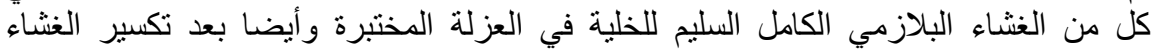

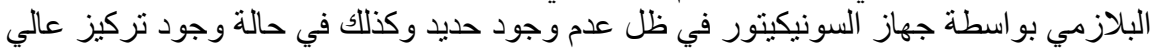

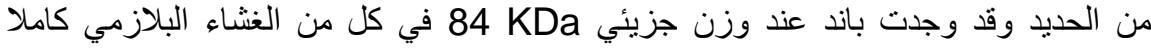

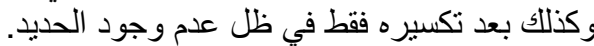

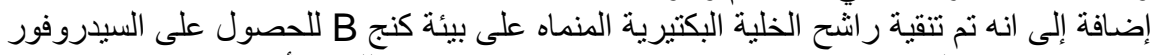

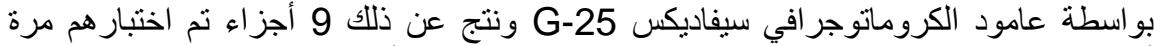

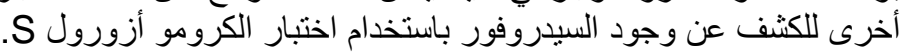

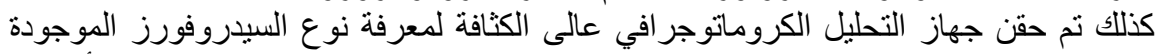

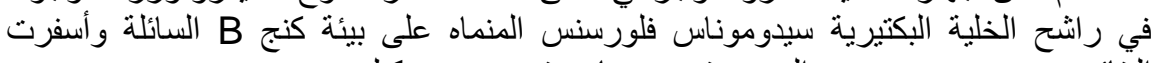

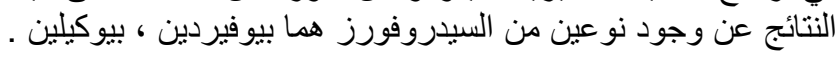

كلية الزراعة - جامعة المنصورة كلية الزراعة - جامعة الاسكندرية - جامعة المنورة
قام بتحكيم البحث

أ.د / السيد عبد البدي المجيد فيظ الله أ.د / عبد الحميد محمد طر ابيه فيله 